\title{
BENEFITS AND RISKS OF ENDOVASCULAR TREATMENT IN PATIENTS WITH PROXIMAL VERTEBRAL ARTERY STENOSIS
}

\section{DOBITI I RIZICI ENDOVASKULARNOG TRETMANA PACIJENATA SA STENOZOM VERTEBRALNE ARTERIJE}

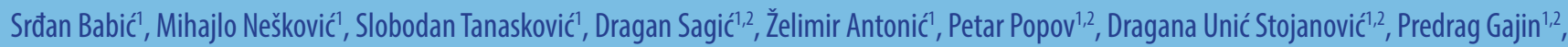
Predrag Matić, ${ }^{1,2}$, Đorđe Radak ${ }^{1,2,3}$

\section{Summary}

Extracranial vertebral artery stenosis is an important cause of posterior circulation ischemic stroke. There are several therapeutic approaches in patients with vertebral artery (VA) stenosis, including medical, endovascular and surgical treatment. This review should summarize the literature concerning endovascular treatment (EVT) of extracranial VA stenosis.

By scanning reference lists of other review articles and by searching electronic database MEDLINE by using major MESH term „vertebrobasilar insufficiency/therapy" from January 2010 to April 2015, studies that included patients of any race, age and sex with symptomatic or asymptomatic atherosclerotic stenotic VA disease were identified. Periprocedural transitory ischemic attack (TIA) and stroke, and death within 30 days of the treatment were our primary interest and symptom resolution was secondary outcome measure.

We found 12 retrospective studies with prospectively collected data and one additional comparative study of VA angioplasty/stenting and medical treatment was found. Percutaneous luminal angioplasty or stenting alone, or their combinations were performed in 693 patients (726 lesions). Periprocedural TIA or stroke occurred in 14 out of 693 patients (2.0\%) and 30 days mortality in $1(0.15 \%)$. A wide range of restenosis rates (3-58\%) was reported.

The literature shows that EVT of extracranial VA stenosis is safe and efficient. The vast majority of patients remain symptom free after the procedure, despite the restenosis rate.

\section{Sažetak}

Ekstrakranijalna stenoza vertebralnih arterija je značajan uzrok ishemijskog moždanog udara u predelu zadnjeg sliva. Postoji više izbora mogućnosti lečenja, uključujući medikamentni, endovaskularni i hirurški pristup.

Analizirana je literatura o endovaskularnom lečenju ekstrakranijalne stenoze vertebralnih arterija sa akcentom na indikacijama i preproceduralnim simptomima. Uvidom u radove i pretragom elektronske baze podataka MEDLINE koristeći MESH izraz „vertebrobasilar insufficiency/therapy“ u periodu od januara 2010 do aprila 2015 godine, identifikovane su studije sa stenozom vertebalnih arterija.

Pronađeno je 12 studija sa prospektivno sakupljenim podacima i jedna komparativna studija koja poredi endovaskularni i medikamentni tretman. Nije bilo studija koje porede endovaskularni sa hirurškim pristupom. Endovaskularni tretman je urađen u 693 pacijenata (726 lezija). Periproceduralni TIA ili moždani udar javio se u 14 od 693 pacijenata (2,0\%), sa 30-to dnevnim mortalitetom od 0.15\%. Prijavljeni su različiti podaci o učestalosti restenoze (3-58\%).

Literatura je pokazala da je endovaskularni tretman ekstrakranijalne stenoze vertebralnih arterija bezbedna i efikasna procedura.Veći deo pacijenata nije imao ponavljanje simptome posle lečenja, nezavisno od učestalosti restenoze.

\section{INTRODUCTION}

Approximately one quarter of all ischemic strokes affect the brain tissue supplied by posterior cerebral circulation $(1,2)$ and extracranial vertebral artery (VA) stenosis is the cause in almost $20 \%$ of patients $(3-6)$. Contrary to precisely defined indications for carotid or subclavian artery (7) steno-occlusive lesion, indications for VA disease are still vague. Ambiguous symptoms can be easily misjudged and attributed to carotid and subclavian artery disease, as well as to otogenic, cardiac or postural hypotensive disorders. Also, there is a degree of difficulty in diagnosing this condition and ac- cording to the current guidelines insufficient data leads to level $\mathrm{C}$ of evidence for VA stenosis diagnosis (8).

There are several therapeutic approaches in patients with VA stenosis, including a medical, endovascular and surgical treatment. Firstly, stroke prevention therapy, consisting of antiplatelet agents and statins is prescribed to patients with VA stenosis, with an exception of cases with posterior circulation transient ischemic attack (TIA) $(9,10)$. However, if this best medical therapy fails to bring about any improvement of symptoms 
after 2-3 months, the stenotic VA lesion should be treated $(11,12)$. There are a number of surgical techniques used to treat VA disease (13) all of which are technically demanding, due to the unique anatomy of vertebral arteries. On the other hand, endovascular interventions have been proven relatively safe and efficient, although variable restenosis rates have been reported, both with bare - metal and drug - eluted stents (12, 14-16).

The main limiting factor for clarifying indications for every treatment approach is an insufficient number of controlled prospective, randomized studies with a larger study group cohort. Also, published papers mostly report results of symptomatic high - degree extracranial VA stenosis, with a limitation in the asymptomatic patients study $(14,17)$. This review should summarize the literature on the treatment of extracranial VA stenosis with a focus on indications and symptom resolution after intervention $(11,12,14-24)$.

\section{MeTHODS}

We pre-specified the objectives and methods of this systematic review. Our main points of interest were studies reporting the endovascular treatment (EVT) of extracranial VA stenosis. Retrospective and prospective case series were considered, as well as comparative trials of endovascular treatment versus the best medical therapy or open surgery. Every case series report needed to have a minimum of 25 patients, of any race, age and sex with symptomatic or asymptomatic VA atherosclerotic disease. We recorded ischemic attacks, both short - lasting ones (TIA) and permanent ones (stroke), as well as fatal outcomes as a result of any cause 30 days after the treatment as primary outcome measures. Our secondary interest points were the symptoms of VA stenosis and reoccurrence of the previously persistent symptoms.

Studies were identified by scanning reference lists of other review articles and by searching electronic database MEDLINE using PubMed provider from January 2010 to April 2015. For searching through PubMed we used the major MESH term „vertebrobasilar insufficiency/therapy". We included only English language full - text access articles. We excluded the articles which provided insufficient data about our outcome measures. Eligibility assessment was performed in an unblinded standardized manner.

Firstly, we developed a data extraction sheet with the following parameters: demographic data, presenting symptoms, type of intervention (PTA or stenting, or both) and outcome (periprocedural TIA and stroke, 30day mortality, follow-up length, recurrent vertebrobasilar circulation symptoms and restenosis rate). Having created data sheet, we performed a subgroup analysis.

Table 1. Demographic data

\begin{tabular}{|c|c|c|c|c|c|c|}
\hline & $\begin{array}{c}\text { Patients } \\
\qquad \mathrm{N}\end{array}$ & $\begin{array}{c}\text { Arteries } \\
\mathbf{N}\end{array}$ & $\begin{array}{c}\text { Mean age } \\
\text { (years) }\end{array}$ & Male/female & $\begin{array}{c}\text { Contralateral VA } \\
\text { disease } \\
\text { N }\end{array}$ & $\begin{array}{c}\text { Anterior } \\
\text { circulation } \\
\text { disease } \\
\mathrm{N}\end{array}$ \\
\hline Chen 2011[15] & 47 & 49 & 60 & $32 / 15$ & 30 & 8 \\
\hline Edgell 2013[18] & 148 & 149 & 66 & $108 / 38$ & 116 & 1 \\
\hline Jenkins 2001[16] & 32 & 38 & 67 & $22 / 10$ & l & 24 \\
\hline Li 2014[20] & 32 & 32 & 66 & $28 / 4$ & 18 & 6 \\
\hline Lin 2006[19] & 80 & 90 & 72 & $64 / 16$ & 26 & 50 \\
\hline Parkhutik 2010[17] & 28 & 29 & 64 & $21 / 7$ & 9 & 17 \\
\hline Radak 2014[11] & 73 & 73 & 61 & $33 / 40$ & 39 & 9 \\
\hline Taylor 2009[14] & 72 & 77 & 62 & $55 / 17$ & 47 & 1 \\
\hline Vajda 2009[21] & 48 & 52 & 68 & $36 / 12$ & 24 & I \\
\hline Werner 2010[12] & 28 & 28 & 66 & $17 / 11$ & 5 & 17 \\
\hline Weber 2005[22] & 36 & 38 & 61 & $27 / 9$ & 34 & 1 \\
\hline Zhou 2010[23] & 61 & 63 & 64 & $45 / 16$ & 37 & 1 \\
\hline Coward 2007[24] & 8 & 8 & 63 & $5 / 3$ & I & I \\
\hline
\end{tabular}


Table 2. Indications and type of procedure

\begin{tabular}{|c|c|c|}
\hline & Indications for treatment & Type of procedure \\
\hline Chen 2011 [15] & Symptomatic VA stenosis $>70 \%$ refractory to MT & Direct stenting (DES) \\
\hline Edgell 2013 [18] & Symptomatic VA stenosis & Direct stenting \\
\hline Jenkins 2001 [16] & Symptomatic VA stenosis $>70 \%$ refractory to MT & Direct stenting \\
\hline Li 2014[20] & $\begin{array}{l}\text { Symptomatic VA stenosis }>70 \% \text { refractory to MT with } 2 \text { risk factors } \\
\text { for atherosclerosis }\end{array}$ & Direct stenting \\
\hline Lin 2006 [19] & $\begin{array}{l}\text { Symptomatic VA stenosis }>75 \% \text { or VA stenosis }>50 \% \text { with con- } \\
\text { tralateral occlusion refractory to MT }\end{array}$ & Direct stenting \\
\hline Parkhutik 2010 [17] & $\begin{array}{l}\text { Symptomatic VA stenosis }>50 \% \text { or asymptomatic VA stenosis }>50 \% \\
\text { with carotid artery stenosis }\end{array}$ & PTA with stenting \\
\hline Radak 2014 [11] & Symptomatic VA stenosis $>70 \%$ & PTA, PTA with stenting, direct stenting \\
\hline Taylor 2009 [14] & $\begin{array}{l}\text { Symptomatic or asymptomatic VA stenosis with contralateral of ca- } \\
\text { rotid artery significant stenosis }\end{array}$ & Direct stenting \\
\hline Vajda 2009 [21] & Not defined & Direct stenting (DES) \\
\hline Werner 2010 [12] & Symptomatic VA stenosis $>50 \%$ refractory to MT & Direct stenting (DES) \\
\hline Weber 2005 [22] & Symptomatic VA stenosis $>70 \%$ refractory to MT & Direct stenting \\
\hline Zhou 2010 [23] & Symptomatic VA stenosis $>50 \%$ & Direct stenting \\
\hline Coward 2007[24] & Symptomatic VA stenosis $>50 \%$ & PTA, Stenting \\
\hline
\end{tabular}

Abbreviation: VA, vertebral artery; MT, medical therapy; DES drug-eluting stent.

\section{RESULTS}

The results of our search included 13 studies: 12 retrospective studies and one additional comparative study of VA angioplasty/stenting and medical treatment were found. There were no studies comparing the outcomes of open surgery and EVT.

EVT of the VA was performed in 693 patients (726 lesions). The mean number of patients in the chosen articles was 53 . The majority of patients were men $(n=493$, $72 \%$ ), and the population age was from 60 to 72 years. Contralateral VA disorders (stenosis, hypoplasia or missing) were found in 385 out of 653 patients (59\%). Significant lesions of the anterior circulation of the brain were recorded in 7 studies and were present in 131 out of 320 patients, for a prevalence of $41 \%$. Four articles provided status information of the concomitant ipsilateral subclavian artery stenosis which was found in 32 (5\%) patients. However, in several articles this condition was an exclusion criterion. (Table 1).

Indications for the treatment were diverse throughout the studies. The most solid criterion was a high - grade (50-75\%) symptomatic vertebral artery stenosis which was refractory to best medical treatment for several months. $[12,23,24]$ In 8 studies NASCET criteria were used for measuring the vessel stenosis. The disease was presented with persisting symptoms of posterior circulation insufficiency or with previous ischemic events on the same territory. Symptoms such as vertigo, visual and speech disturbances, gait disorders, syncope, drop attacks, heminumbness, hemiparesis and headaches were specified in 7 articles, in which part of them were classified as TIA or stroke. (Table 4). Some of the groups posed indication for treating asymptomatic patients with high - grade vertebral artery stenosis with concomitant stenosis of other supraaortic branches.

Stenting of the ostial portion (V1 segment) of the VA was the most common procedure in every study, being either primary stenting or combined with pre- and post - dilation. The most common types of stent used were balloon - expanding and self - expanding bare - metal stents, although antiproliferative drug - eluting stents were used in only 3 studies. PTA alone in the treatment of VA was used sporadically. (Table 2).

All the articles reported administering pre - procedural dual - antiplatelet therapy (aspirin in 100-325 mg/ day with clopidogrel $75 \mathrm{mg}$ daily or ticlopidine $250 \mathrm{mg}$ twice a day), as well as its continuance for at least several months. Periprocedural TIA or stroke occurred in 14 out of 693 patients (2.0\%), including those on the anterior circulation territory. Only one patient died within 30 days of the intervention and the death was related to a preceding major stroke, which makes the 30-day mortality rate of $0.15 \%$. No data were found related to the periprocedural TIA or stroke. 
Table 3. Outcome measures

\begin{tabular}{|c|c|c|c|c|c|c|c|c|}
\hline & $\begin{array}{c}\text { Periprocedural } \\
\text { TIA/Stroke } \\
\text { (n) }\end{array}$ & $\begin{array}{c}30 \text { day } \\
\text { mortality } \\
\text { (n) }\end{array}$ & $\begin{array}{l}\text { Median } \\
\text { follow-up } \\
\text { (months) }\end{array}$ & $\begin{array}{c}\text { Patients } \\
\text { followed-up } \\
\text { (n) }\end{array}$ & $\begin{array}{c}\text { Restenosis } \\
\text { rate }(\%)\end{array}$ & $\begin{array}{c}\text { Recurrent } \\
\text { symptoms } \\
\text { (n) }\end{array}$ & $\begin{array}{l}\text { Re-inter- } \\
\text { vention rate } \\
(\mathbf{n}, \%)\end{array}$ & $\begin{array}{l}\text { Late mor- } \\
\text { tality (n) }\end{array}$ \\
\hline Chen 2011 [15] & 0 & 0 & 28.3 & 38 & 4.2 & 2 & 0 & 2 \\
\hline Edgell 2013 [18] & 1 & 0 & 7 & 58 & 15.5 & 5 & I & 0 \\
\hline Jenkins 2001 [16] & 1 & 0 & 11 & 32 & I & 1 & 1 & I \\
\hline Li 2014[20] & 0 & 0 & 12.5 & 32 & 3.1 & 0 & 0 & 0 \\
\hline Lin 2006 [19] & 3 & 0 & 38 & 79 & 28 & 1 & $1(1.3 \%)$ & 1 \\
\hline $\begin{array}{l}\text { Parkhutik } 2010 \\
\text { [17] }\end{array}$ & 1 & 0 & 32 & 28 & 5.3 & 1 & 1 & 0 \\
\hline Radak 2014 [11] & 1 & 0 & 44.3 & 69 & 10.3 & 4 & 4 & 7 \\
\hline Taylor 2009 [14] & 3 & 1 & 9 & 66 & 58 & 9 & $23(35 \%)$ & 2 \\
\hline Vajda 2009 [21] & 0 & 0 & 8 & 48 & 13.00 & 0 & I & 0 \\
\hline Werner 2010 [12] & 0 & 0 & 16 & 28 & 21.10 & 6 & 0 & 0 \\
\hline Weber 2005 [22] & 1 & 0 & 11 & 26 & 46.00 & 1 & 5 & 0 \\
\hline Zhou 2010 [23] & 1 & 0 & 13 & 61 & 31.00 & 3 & $5(7.9 \%)$ & 0 \\
\hline Coward 2007[24] & 2 & 0 & 54 & 8 & 43 & 2 & $1(13 \%)$ & 2 \\
\hline
\end{tabular}

Follow-up data reported in all 13 articles were with a variable, between 7 and 54 months. Five articles reported a follow-up of $<12$ months (336 patients), another five 12-36 months (196 patients), and the last three articles provided a follow-up of $>36$ months (161 patients). (Table 3).
Recurrent symptoms of vertebrobasilar insufficiency were noted in 35 patients (5\%). A wide range of restenosis rates (3-58\%) was reported. Most authors defined restenosis as a presence of recurrent stenosis $>50 \%$ in the previously treated segment of the vertebral artery.

Table 4. Symptoms of VA lesion

\begin{tabular}{|c|c|c|c|c|c|c|c|c|c|c|}
\hline & $\begin{array}{c}\text { Diz- } \\
\text { ziness } \\
\text { (Vertigo) } \\
(\%)\end{array}$ & $\begin{array}{c}\text { Hemi- } \\
\text { numb- } \\
\text { ness (\%) }\end{array}$ & $\begin{array}{l}\text { Hemipa- } \\
\text { resis (\%) }\end{array}$ & $\begin{array}{l}\text { Visual dis- } \\
\text { turbances } \\
(\%)\end{array}$ & $\begin{array}{c}\text { Gait } \\
\text { distur- } \\
\text { bances } \\
(\%)\end{array}$ & $\begin{array}{c}\text { Previ- } \\
\text { ous PC } \\
\text { stroke } \\
(\%)\end{array}$ & $\begin{array}{l}\text { Recur- } \\
\text { rent } \\
\text { syncope } \\
(\%)\end{array}$ & $\begin{array}{c}\text { Drop } \\
\text { attack } \\
(\%)\end{array}$ & $\begin{array}{c}\text { Speech } \\
\text { distur- } \\
\text { bances } \\
(\%)\end{array}$ & $\begin{array}{c}\text { Headache } \\
\text { (\%) }\end{array}$ \\
\hline Chen 2011 & 80 & 40.0 & 63 & 27 & 23.0 & 17 & 0 & 0 & 0 & 0 \\
\hline Edgell 2010 & 7.43 & 0 & 0 & 0 & 0 & 94.5 & 0 & 0 & 0 & 0 \\
\hline Jenkins 2001 & 65.7 & 0 & 0 & 32.4 & 7.6 & 8.6 & 11.4 & 4.8 & 0 & 0 \\
\hline Li 2014 & 31.2 & 0 & 0 & 6.2 & 18.8 & 43.8 & 0 & 0 & 0 & 0 \\
\hline Lin 2006 & 70 & 0 & 0 & 4.0 & 11.0 & 20 & 25.0 & 18.0 & 0 & 0 \\
\hline $\begin{array}{l}\text { Parhutik } \\
2010\end{array}$ & $\mathrm{n} / \mathrm{a}$ & $\mathrm{n} / \mathrm{a}$ & $\mathrm{n} / \mathrm{a}$ & $\mathrm{n} / \mathrm{a}$ & $\mathrm{n} / \mathrm{a}$ & $\mathrm{n} / \mathrm{a}$ & $\mathrm{n} / \mathrm{a}$ & $\mathrm{n} / \mathrm{a}$ & $\mathrm{n} / \mathrm{a}$ & $\mathrm{n} / \mathrm{a}$ \\
\hline Radak 2014 & 49.4 & 0 & 0 & 13.7 & $1.4 \%$ & 16.3 & 12.3 & 0 & 4.1 & 2.8 \\
\hline Taylor 2009 & $\mathrm{n} / \mathrm{a}$ & $\mathrm{n} / \mathrm{a}$ & $\mathrm{n} / \mathrm{a}$ & $\mathrm{n} / \mathrm{a}$ & $\mathrm{n} / \mathrm{a}$ & $\mathrm{n} / \mathrm{a}$ & $\mathrm{n} / \mathrm{a}$ & $\mathrm{n} / \mathrm{a}$ & $\mathrm{n} / \mathrm{a}$ & $\mathrm{n} / \mathrm{a}$ \\
\hline Vajda 2010 & $\mathrm{n} / \mathrm{a}$ & $\mathrm{n} / \mathrm{a}$ & $\mathrm{n} / \mathrm{a}$ & $\mathrm{n} / \mathrm{a}$ & $\mathrm{n} / \mathrm{a}$ & $\mathrm{n} / \mathrm{a}$ & $\mathrm{n} / \mathrm{a}$ & $\mathrm{n} / \mathrm{a}$ & $\mathrm{n} / \mathrm{a}$ & $\mathrm{n} / \mathrm{a}$ \\
\hline Werner 2010 & 71.4 & 0 & 0 & 7.2 & 0 & 0 & 21.4 & 0 & 0 & 0 \\
\hline Weber 2005 & $\mathrm{n} / \mathrm{a}$ & $\mathrm{n} / \mathrm{a}$ & $\mathrm{n} / \mathrm{a}$ & $\mathrm{n} / \mathrm{a}$ & $\mathrm{n} / \mathrm{a}$ & $\mathrm{n} / \mathrm{a}$ & $\mathrm{n} / \mathrm{a}$ & $\mathrm{n} / \mathrm{a}$ & $\mathrm{n} / \mathrm{a}$ & $\mathrm{n} / \mathrm{a}$ \\
\hline Zhou 2011 & $\mathrm{n} / \mathrm{a}$ & $\mathrm{n} / \mathrm{a}$ & $\mathrm{n} / \mathrm{a}$ & $\mathrm{n} / \mathrm{a}$ & $\mathrm{n} / \mathrm{a}$ & $\mathrm{n} / \mathrm{a}$ & $\mathrm{n} / \mathrm{a}$ & $\mathrm{n} / \mathrm{a}$ & $\mathrm{n} / \mathrm{a}$ & $\mathrm{n} / \mathrm{a}$ \\
\hline $\begin{array}{l}\text { Coward } \\
2007\end{array}$ & $\mathrm{n} / \mathrm{a}$ & $\mathrm{n} / \mathrm{a}$ & $\mathrm{n} / \mathrm{a}$ & $\mathrm{n} / \mathrm{a}$ & $\mathrm{n} / \mathrm{a}$ & 43.75 & $\mathrm{n} / \mathrm{a}$ & $\mathrm{n} / \mathrm{a}$ & $\mathrm{n} / \mathrm{a}$ & $\mathrm{n} / \mathrm{a}$ \\
\hline
\end{tabular}


However, there was a significant discrepancy throughout the articles in defining it.

\section{Discussion}

Atherosclerotic stenosis of vertebral arteries is the main cause of ischemic posterior circulation stroke and as such it can have debilitating consequences $(1,2,4)$. Aside from the embolising potential, it can generate symptoms which are often attributed to other organ diseases. Vague natural history and some degree of difficulty in imaging the vertebral artery makes it largely undiagnosed and consequentially underestimated (10). There are no definite indications for the treatment of VA stenosis to this day (8).

The initial medical therapy for stroke prevention includes antiplatelet drugs and statins in high doses. Along with the reduction of established atherosclerosis risk factors it can contribute to the improvement of symptoms $(9,10)$. The more invasive treatment is applied if patients are refractory to best medical therapy for several months. Surgical procedures include endarterectomy, autologous venous or arterial bypassing and transposition of VA to carotid arteries $(25,27)$. However, these reconstructions were followed with high rates of periprocedural complications (cranial neuropathies, lymphocele, wound infections and periprocedural TIAs and strokes). On the other hand, the latest papers report significantly less postoperative cerebrovascular events (27). It's become clear that VA surgery should be done in specialized centres with considerable experience in this field, due to the complexity of each procedure. Endovascular treatment emerged as a promising solution for VA stenosis and there are a growing number of papers supporting this approach $(11,18,20,21)$.

One of disadvantages in the best therapeutic option is the lack of comparative studies in the literature. The only prospective randomized study we included in the review, which compared best medical therapy with PTA and primary stenting, reported four TIAs and two strokes, but none of them on the territory of posterior circulation during the follow-up period in either treatment arms. However these results shouldn't be taken for granted due to the small number of patients ( 8 in each treatment arm) (24).

By summarizing the data from the case series we included in our review we showed that the endovascular approach is safe and efficient in treating VA stenosis. Combined periprocedural TIA/stroke rate after EVT of VA stenotic lesion is $2.0 \%$ and 30 -day mortality is $0.15 \%$.

The use of distal protection devices is still controversial, mostly because of the small vessel diameter (28-30). Also, the use of embolism protection devices is difficult in cases with high - grade stenosis and respect of small diameter of vertebral artery. Something similar is recommended by Wehman et al. (30) - the use of an embolism protection device for larger VA (diameter $>3.5$ $\mathrm{mm}$ ), in patients that have a favourable angle of the VA orifice and for the treatment of ulcerated lesions.

Restenosis rates are variable through the studies and they range from $3.1-46 \%$. Poor angiographic follow-up, different definitions of restenosis as well as the dissemblance in endovascular procedures make comparing restenosis rates very hard. Some authors used coronary drug - eluting stents (DES) in their procedures to inhibit the process of neointimal hyperplasia $(12,15,21)$. It seems that the use of these stents can contribute to a decline in restenosis rates. Also, most of the restenosis were asymptomatic, and only 35 out of 693 patients (5\%) had recurrent symptoms during the follow-up period.

The main limitation of our review is the lack of data and uniform settings in studies included. Also, there were considerable differences in patient selection, endovascular procedure protocols and definitions of some outcome measures.

However, as it could be seen from this review, a low complication rate after EVT, including neurological mortality, promotes this procedure as the primary therapeutic option in patients with symptomatic VA stenosis. Also, symptom resolution after an intervention enables good life quality and prevention of posterior circulation stroke.

In this review we focused on EVT of the VA stenosis. Following presented data from the surgical studies (2527), and the complication rate, surgical treatment may be the only viable option in the patients with failed endovascular treatment who have lesions or anatomy unfavourable to EVT.

\section{Conclusion}

The literature shows that endovascular treatment of vertebral artery stenosis is a safe and efficient procedure. The vast majority of patients remain symptom - free after the procedure. However, following presented data and results from this review, it should be kept in mind for some future guidelines that clear indications for VA stenotic lesion should be made. 


\section{References}

1. Bamford J, Sandercock P, Dennis M, Burn J, Warlow C. Classification and natural history of clinically identifiable subtypes of cerebral infarction. Lancet. 1991;337(8756):1521-6.

2. Bogousslavsky J, Van Melle G, Regli F. The Lausanne Stroke Registry: analysis of 1,000 consecutive patients with first stroke. Stroke. 1988;19(9):1083-92.

3. Caplan LR, Amarenco P, Rosengart A, Lafranchise EF, Teal PA, Belkin $\mathrm{M}$, et al. Embolism from vertebral artery origin occlusive disease. Neurology. 1992;42(8):1505-12

4. George B, Laurian C. Vertebro-basilar ischaemia. Its relation to stenosis and occlusion of the vertebral artery. Acta Neurochir (Wien). 1982;62(3-4):287-95.

5. Koroshetz WJ, Ropper AH. Artery-to-artery embolism causing stroke in the posterior circulation. Neurology. 1987;37(2):292-5.

6. Pessin MS, Daneault N, Kwan ES, Eisengart MA, Caplan LR. Local embolism from vertebral artery occlusion. Stroke. 1988;19(1):112-5.

7. Babic S, Sagic D, Radak D, Antonic Z, Otasevic P, Kovacevic V, et al. Initial and long-term results of endovascular therapy for chronic total occlusion of the subclavian artery. Cardiovasc Intervent Radiol. 2012;35(2):255-62.

8. Brott TG, Halperin JL, Abbara S, Bacharach JM, Barr JD, Bush RL, et al. 2011 ASA/ACCF/AHA/AANN/AANS/ACR/ASNR/CNS/SAIP/ SCAI/SIR/SNIS/SVM/SVS guideline on the management of patients with extracranial carotid and vertebral artery disease: executive summary. Stroke. 2011;42(8):e420-63.

9. O’Regan C, Wu P, Arora P, Perri D, Mills EJ. Statin therapy in stroke prevention: a meta-analysis involving 121,000 patients. Am J Med. 2008;121(1):24-33.

10. Collaborative overview of randomised trials of antiplatelet therapy--I: Prevention of death, myocardial infarction, and stroke by prolonged antiplatelet therapy in various categories of patients. Antiplatelet Trialists' Collaboration. BMJ. 1994;308(6921):81-106.

11. Radak D, Babic S, Sagic D, Tanaskovic S, Kovacevic V, Otasevic P, et al. Endovascular treatment of symptomatic high-grade vertebral artery stenosis. J Vasc Surg. 2014;60(1):92-7.

12. Werner M, Braunlich S, Ulrich M, Bausback Y, Schuster J, Lukhaup A, et al. Drug-eluting stents for the treatment of vertebral artery origin stenosis. J Endovasc Ther. 2010;17(2):232-40.

13. Berguer R, Morasch MD, Kline RA. A review of 100 consecutive reconstructions of the distal vertebral artery for embolic and hemodynamic disease. J Vasc Surg. 1998;27(5):852-9.

14. Taylor RA, Siddiq F, Memon MZ, Qureshi AI, Vazquez G, Hayakawa $\mathrm{M}$, et al. Vertebral artery ostial stent placement for atherosclerotic stenosis in 72 consecutive patients: clinical outcomes and follow-up results. Neuroradiology. 2009;51(8):531-9.

15. Chen X, Huang Q, Hong B, Zhang Y, Xu Y, Liu J. Drug-eluting stent for the treatment of symptomatic vertebral origin stenosis: Long-term results. J Clin Neurosci. 2011;18(1):47-51.

16. Jenkins JS, White CJ, Ramee SR, Collins TJ, Chilakamarri VK, McKinley $\mathrm{KL}$, et al. Vertebral artery stenting. Catheter Cardiovasc Interv.
2001;54(1):1-5

17. Parkhutik V, Lago A, Tembl JI, Aparici F, Vazquez V, Mainar E. Angioplasty and stenting of symptomatic and asymptomatic vertebral artery stenosis: to treat or not to treat. Eur J Neurol. 2010;17(2):267-72.

18. Edgell RC, Zaidat OO, Gupta R, Abou-Chebl A, Linfante I, Xavier A, et al. Multicenter study of safety in stenting for symptomatic vertebral artery origin stenosis: results from the Society of Vascular and Interventional Neurology Research Consortium. J Neuroimaging. 2013;23(2):170-4.

19. Lin YH, Liu YC, Tseng WY, Juang JM, Hung CS, Lin JW, et al. The impact of lesion length on angiographic restenosis after vertebral artery origin stenting. Eur J Vasc Endovasc Surg. 2006;32(4):379-85.

20. Li Z, Zhang Y, Hong B, Deng B, Xu Y, Zhao W, et al. Stenting of symptomatic vertebral artery ostium stenosis with self-expanding stents. J Clin Neurosci. 2014;21(2):274-7.

21. Vajda Z, Miloslavski E, Guthe T, Fischer S, Albes G, Heuschmid A, et al. Treatment of stenoses of vertebral artery origin using short drug-eluting coronary stents: improved follow-up results. AJNR Am J Neuroradiol. 2009;30(9):1653-6.

22. Weber W, Mayer TE, Henkes H, Kis B, Hamann GF, Holtmannspoetter $\mathrm{M}$, et al. Efficacy of stent angioplasty for symptomatic stenoses of the proximal vertebral artery. Eur J Radiol. 2005;56(2):240-7.

23. Zhou Z, Yin Q, Xu G, Yue X, Zhang R, Zhu W, et al. Influence of vessel size and tortuosity on in-stent restenosis after stent implantation in the vertebral artery ostium. Cardiovasc Intervent Radiol. 2011;34(3):481-7.

24. Coward LJ, McCabe DJ, Ederle J, Featherstone RL, Clifton A, Brown $\mathrm{MM}$, et al. Long-term outcome after angioplasty and stenting for symptomatic vertebral artery stenosis compared with medical treatment in the Carotid And Vertebral Artery Transluminal Angioplasty Study (CAVATAS): a randomized trial. Stroke. 2007;38(5):1526-30.

25. Borhani Haghighi A, Edgell RC, Cruz-Flores S, Zaidat OO. Vertebral artery origin stenosis and its treatment. J Stroke Cerebrovasc Dis. 2011;20(4):369-76

26. Berguer R, Flynn LM, Kline RA, Caplan L. Surgical reconstruction of the extracranial vertebral artery: management and outcome. J Vasc Surg. 31:9-18, 2000

27. Rangel-Castilla L, Kalani MY, Cronk K, Zabramski JM, Russin JJ, Spetzler RF: Vertebral artery transposition for revascularization of the posterior circulation: a critical assessment of temporary and permanent complications and outcomes. J Neurosurg. 122:671-667, 2015

28. Mintz EP, Gruberg L, Kouperberg E, Beyar R. Vertebral artery stenting using distal emboli protection and transcranial Doppler. Cathet Cardiovasc Intervent 2004;61:12-5.

29. Qureshi AI, Kirmani JF, Harris-Lane P, Divani AA, Ahmed S, Ebrihimi A et al. Vertebral artery origin stent placement with distal protection: technical and clinical results. AJNR Am J Neuroradiol 2006; 27: $1140-1145$

30. Wehman JC, Hanel RA, Guidot CA, Guterman LR, Hopkins LN. Atherosclerotic occlusive extracranial vertebral artery disease: indications for intervention, endovascular techniques, short-term and long-term results. J Interv Cardiol 2004; 17: 219-232 